\title{
Are new EU member states catching up with older ones on global agri- food markets?
}

\author{
$\breve{S}$ tefan Bojnec $^{\mathrm{a}^{*}}$ and Imre Fertö ${ }^{\mathrm{b}}$ \\ ${ }^{a}$ University of Primorska, Faculty of Management, Slovenia; ${ }^{b}$ Corvinus University of \\ Budapest and Institute of Economics, Centre for Regional and Economic Studies \\ Hungarian Academy of Sciences, Hungary
}

\section{For publication in Post-Communist Economies}

The paper investigates price and quality competitiveness and comparative advantage in the new and old European Union Member States' agri-food trade on the global market between 2000 and 2011. The empirical results show that the new and old Member States have become more similar in successful agri-food competitiveness and comparative advantages. The shares of successful price and successful quality competition were greater in the structure of the two-way matched agri-food trade than the shares of unsuccessful price and unsuccessful quality competition. Only the one-way export share or only the oneway import share was less important in their agri-food trade structures. Successful price competition and successful quality competition were consistent with revealed comparative advantage as confirmed by the duration analysis.

Keywords: Price competition, Quality competition; One-way trade; Comparative advantage; New and old European Union member states

* Corresponding author. Tel.: +386 5610 2046; fax: +386 56102015 .

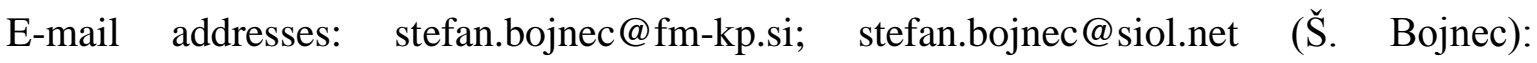
imre.ferto@uni-corvinus.hu; ferto.imre@krtk.mta.hu (I. Fertő). Tel.: +36 1 3092665; fax: +3613193136.

\section{Acknowledgements}

This publication was generated as part of the COMPETE Project, Grant Agreement No. 312029 (http://www.compete-project.eu/), with financial support from the European Community under the $7^{\text {th }}$ Framework Programme. 
The European Union (EU) failed to achieve the objective of the Lisbon strategy to become the most competitive region in the world by 2010. The reasons for the failure of this optimistic objective might be different according to each of the EU-27 countries and different economic sectors. The increasing integration of agri-food products in global markets might strengthen competitive pressures for European agri-food sectors leading to declining EU agri-food competitiveness (FoodDrinkEurope 2012, 2014). The declining competitiveness of European agriculture is already documented in EU policy documents (e.g. Wijnands et al. 2007) and highlighted the need to improve agri-food export competitiveness in global markets (Commission of the European Communities 2011).

The various aspects of weakness of agri-food competitiveness in New Member States (EU-12), particularly from post-communist Central and Eastern European (CEE) countries are already well documented in the literature (e.g. Bojnec 2001, Fertő and Hubbard 2003, Majkovič et al. 2007, Fertő 2008, Bojnec and Fertő 2008a, 2009a, 2009b, 2012a, 2012b). The agri-food competitiveness of the Old EU Member States (EU-15) has been also explored and has often focused on single country agri-food competitiveness (Fischer 2010, Carbone and Henke 2012). So far there is no study to compare agri-food competitiveness and comparative advantages between both groups of the EU Member States.

The aim of this paper is to analyse the price and quality competitiveness and the revealed comparative advantage in the global agri-food trade of the old EU-15 (OMS) and the new EU-12 (NMS). The OMS consists of the following countries: Austria, Belgium, Denmark, Finland, France, Germany, Greece, Ireland, Italy, Luxembourg, the Netherlands, Portugal, Spain, Sweden and the United Kingdom. Except for Cyprus and Malta, the NMS consists of the following post-communist countries: Bulgaria, the Czech Republic, Estonia, Hungary, Latvia, Lithuania, Poland, Romania, Slovakia and Slovenia. The focus of the analysis is on the successful price competitiveness and successful quality competitiveness and the consistency of the results with the revealed comparative advantage. The main analysed hypothesis is that the agri-food competitiveness and comparative advantage in the global trade of the NMS has catch-up to the OMS.

The rest of the paper is organized as follows. Next two sections present our methodology and data used. After then we present results for agri-food competitiveness and comparative advantage of the EU-27 Member States and between the NMS and OMS with duration analysis for total agri-food trade. Final section summarizes and concludes. 


\section{Methodology}

Different theoretical and methodological approaches are available to investigate trade types classifying them into various components. The combination of export-to-import unit values has been widely used for assessing trade types, product qualities and price competition categories in matched bilateral trade data (Aiginger 1997, 1998, Ulff and Nielsen 2000, Majkovič et al. 2007). While the export-to-import unit values approach has been criticized because unit values may also differ due to product mix and short run consumers' preferences, the export-to-import unit values are widely used in the empirical trade, price competition and quality competition literature under an assumption, that even with imperfect information, prices tend to reflect quality (Stiglitz 1987) and determine the direction of trade.

Gehlhar and Pick (2002) extend export-to-import unit values as proxies for price combining it with trade balances for direction of trade to classify price competition and non-price competition categories in trade data. Unit values are used as a proxy for price to study which product markets are dominated by price or non-price factors. Trade balances for net directions of trade in matched two-way trade are used to disentangle between successful (surplus) and unsuccessful (deficit) bilateral trade flows at a product level.

Unit values of exports and imports difference by products were used for assessing price and product quality competition in two-way matched trade and the trade balance for each product to categorize success or un-success of trade flows in four categories:

Category 1. Successful price competition when trade surplus is achieved with lower export than import price:

$T B_{(i, j)}>0\left(\right.$ or $\left.X_{(i, j)}>M_{(i, j)}\right)$ and $U V D_{(i, j)}<0\left(\right.$ or $\left.U V_{(i, j)}^{x}<U V_{(i, j)}^{m}\right)$,

Category 2. Unsuccessful price competition when trade deficit is achieved with higher export than import price:

$$
T B_{(i, j)}<0\left(\text { or } X_{(i, j)}<M_{(i, j)}\right) \text { and } U V D_{(i, j)}>0\left(\text { or } U V_{(i, j)}^{x}>U V_{(i, j)}^{m}\right) \text {, }
$$

Category 3. Successful quality competition when trade surplus is achieved with higher export than import price:

$T B_{(i, j)}>0\left(\right.$ or $\left.X_{(i, j)}>M_{(i, j)}\right)$ and $U V D_{(i, j)}>0\left(\right.$ or $\left.U V_{(i, j)}^{x}>U V_{(i, j)}^{m}\right)$,

and

Category 4. Unsuccessful quality competition when trade deficit is achieved with lower export than import price: 
$T B_{(i, j)}<0\left(\right.$ or $\left.X_{(i, j)}<M_{(i, j)}\right)$ and $U V D_{(i, j)}<0\left(\right.$ or $\left.U V_{(i, j)}^{x}<U V_{(i, j)}^{m}\right)$,

where the trade balance $\left(T B_{(i, j)}\right)$ is calculated as:

$T B_{(i, j)}=X_{(i, j)}-M_{(i, j)}$,

where $X_{(i, j)}$ is the value of the $\mathrm{i}$-th product exports from a home (domestic) country (EU27 , respectively) to the $\mathrm{j}$-th partner country (the world or global trade) and $M_{(i, j)}$ is the value of the $\mathrm{i}$-th product imports to the home country from the $\mathrm{j}$-th partner country. In other words, one EU-27 country's exports are another country's imports in the world, and vice versa. The unit value difference $\left(U V D_{(i, j)}\right)$ is calculated as:

$$
U V D_{(i, j)}=U V_{(i, j)}^{x}-U V_{(i, j)}^{m}
$$

where $U V_{(i, j)}^{x}$ is the export unit value, which is calculated as:

$$
U V_{(i, j)}^{x}=X_{(i, j)} / Q_{(i, j)}^{x}
$$

and $U V_{(i, j)}^{m}$ is the import unit value, which is calculated as:

$$
U V_{(i, j)}^{m}=M_{(i, j)} / Q_{(i, j)}^{m} \text {. }
$$

In these calculations, $Q_{(i, j)}^{x}$ and $Q_{(i, j)}^{m}$ are quantities of exports and imports, respectively, between the home EU-27 country $i$ and the partner country j. Trade balances indicate successful or unsuccessful competition in trade. The export-import unit values determine price or quality competition. The four price and quality competition categories approach was applied on the matched two-way trade flows satisfying the simultaneous conditions of the unit value difference and the trade balance by the product. In the matched two-way trade flows in the first and third categories the home EU-27 country i was successful in price and quality competition, respectively. In the second and fourth categories the home EU-27 country was unsuccessful in price and quality competition.

The methodological approach distinguishes between price competition and quality competition categories in the matched two-way trade from non-price competition in the one-way trade. We disentangle the one-way trade from the two-way matched trade. When the one-way trade occurs then the net direction of trade is either surplus or deficit. Therefore, for the one-way trade we distinguish the two possible one-way non-price competition categories, i.e. only one-way export category or only one-way import category, that occur when holds the following conditions (Bojnec and Fertő 2008b, 2012a): 
Only export category: $T B_{(i, j)}>0\left(\right.$ or $\left.X_{(i, j)}>0, M_{(i, j)}=0\right)$ and $U V_{(i, j)}^{m}=0$,

and

Only import category: $T B_{(i, j)}<0$ (or $\left.X_{(i, j)}=0, M_{(i, j)}<0\right)$ and $U V_{(i, j)}^{x}=0$.

We also employ the revealed comparative advantage (RCA) index (Balassa 1965), which is defined as follows:

$\mathrm{RCA}=(\mathrm{Xij} / \mathrm{Xim}) /(\mathrm{Xwj} / \mathrm{Xwm})$

where $\mathrm{X}$ represents exports, $\mathrm{i}$ is a country, $\mathrm{j}$ is a commodity, $\mathrm{m}$ is a set of merchandise commodities, and $\mathrm{w}$ is a set of countries in the world, which are used as the benchmark export markets for comparisons. RCA is based on observed export patterns. It measures a country's exports of a commodity relative to its total exports and to the corresponding export performance of a set of countries, e.g., the world's agro-food exports. If RCA>1, then a country's agri-food comparative advantage on the world market is revealed. In a spite of some critics of the RCA index as export specialization index, such as the asymmetric value problem and problem with logarithmic transformation (De Benedictis and Tamberi 2004) and the importance of simultaneous consideration of the import side (Vollrath 1991), it can provide useful evidence on the competitiveness of the EU-27 agrifood exports on world markets.

Duration analysis of Category 1 - successful price competition, Category 3 - successful quality competition, and RCA index of the NMS and OMS is estimated by the survival function sing the nonparametric Kaplan-Meier product limit estimator (e.g. Cleves et al. 2004, Besedeš and Prusa 2006a and 2006b, Fertő and Soós 2009).

The equality of survival functions between the NMS and OMS agri-food product groups is tested using the Kruskal-Wallis test.

\section{Data}

The United Nations International Trade Statistics UN Comtrade database (UNSD 2013) at the six-digit harmonised commodity description and coding systems (HS6-1996) is used for agri-food trade in the EU-27 Member States to global markets in the 2000-2011 period. The annual sample of agri-food trade as defined by the World Trade Organisation contains 789 product groups at the HS6 digit level. The UN Comtrade database with the World Integrated Trade Solution (WITS) software is used. Value of trade is expressed in US dollars. 


\section{Empirical results}

This part provides the empirical results on the importance of the NMS and OMS agri-food price competition and quality competition categories in the matched two-way trade, and the one-way export/import shares. The RCA indices are calculated for agri-food products with successful price competition (Category 1), successful quality competition (Category 3), and one-way exports. We expect that that these categories are consistent with the RCA $>1$ indices.

\section{Price and quality competition categories and one-way agri-food trade structures}

The proportion of EU-27 Member States agri-food trade that pertains to the Category 1 successful price competition was less important than the proportion of agri-food trade that pertains to the Category 3 - successful quality competition (Figure 1). This implies that successfully matched agri-food trade in similar products tended toward greater higher value added quality differentiation in agri-food exports. This finding is consistent with the EU Member States orientation towards the exporting of higher value-added agri-food products. The share of the one-way exports or one-way imports was of a relatively smaller percentage. These results indicate that the EU-27 Member States are largely competitive in agri-food trade and had advantages in a large part of agri-food trade on the global markets. 


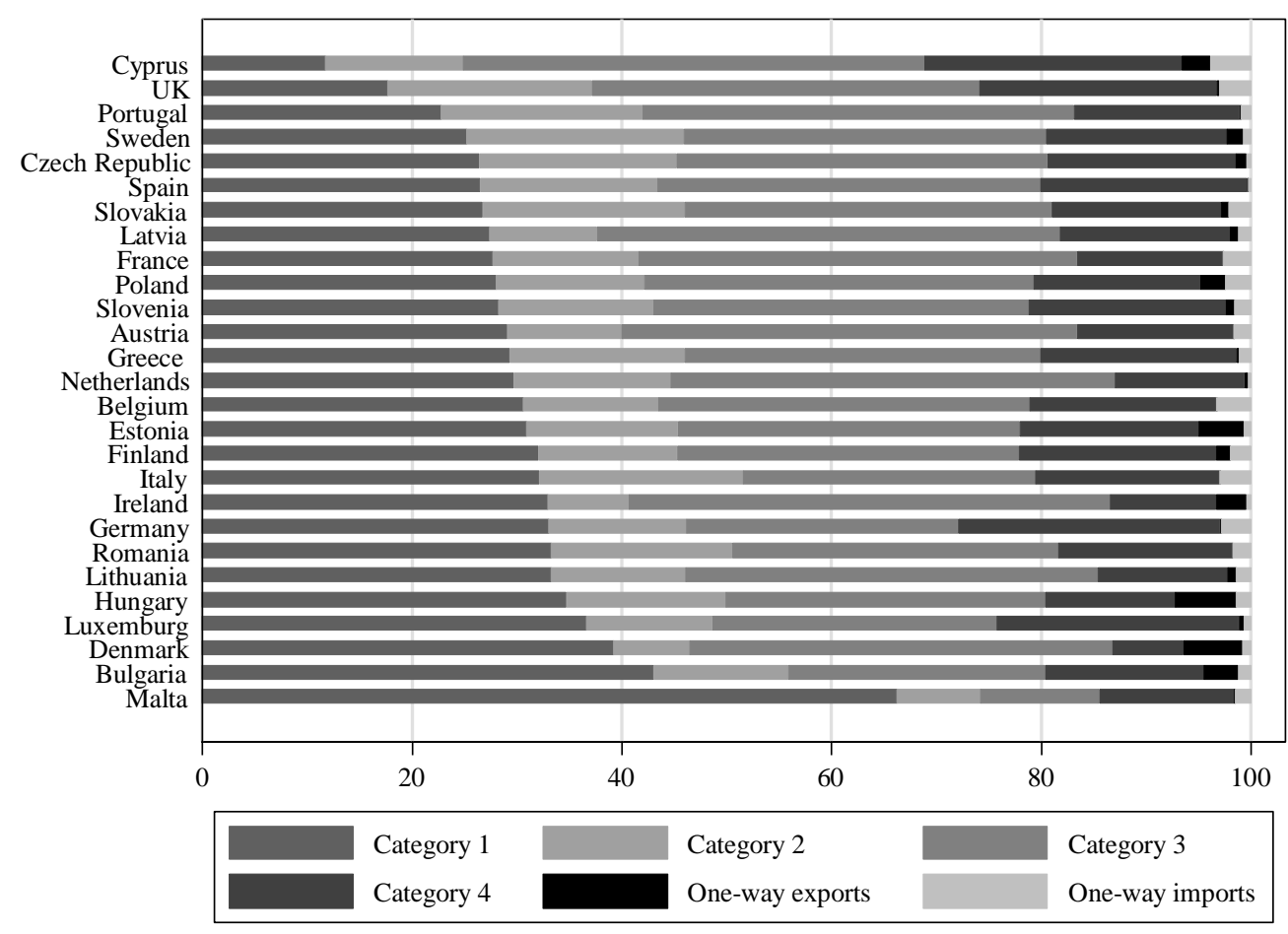

Figure 1. Price and quality competition categories and one-way agri-food trade for EU-27 Member States (structures in \%, mean values, 2000-2011)

Note: Category 1 - successful price competition, Category 2 - unsuccessful price competition, Category 3 - successful quality competition, and Category 4 - unsuccessful quality competition.

Source: Own calculations based on UNSD (2013) Comtrade database with WITS (World Trade Integration Solution) software.

Regarding the percentage of Category 1 - successful price competition, the EU-27 Member States show greater differences among themselves than in Category 3 - successful quality competition. The differences in the percentage of the competition categories among the EU-27 Member States were more often increasing with higher degree of product processing, preparation or preservation for final household consumption. This can be explained by differences in factors of agricultural production and particularly in development of food processing and agri-food international marketing including the development of international agri-food supply chains such as chains of international supermarkets and hypermarkets.

Figure 2 compares the results between the NMS and OMS. The main structures are rather similar. The similarity in the structures of the competition categories and one-way agri-food trade between the NMS and OMS is also analysed by the Kruskal-Wallis tests. They show that there are not significant differences at 5 per cent of significance level in mean values of each category between the NMS and OMS. 


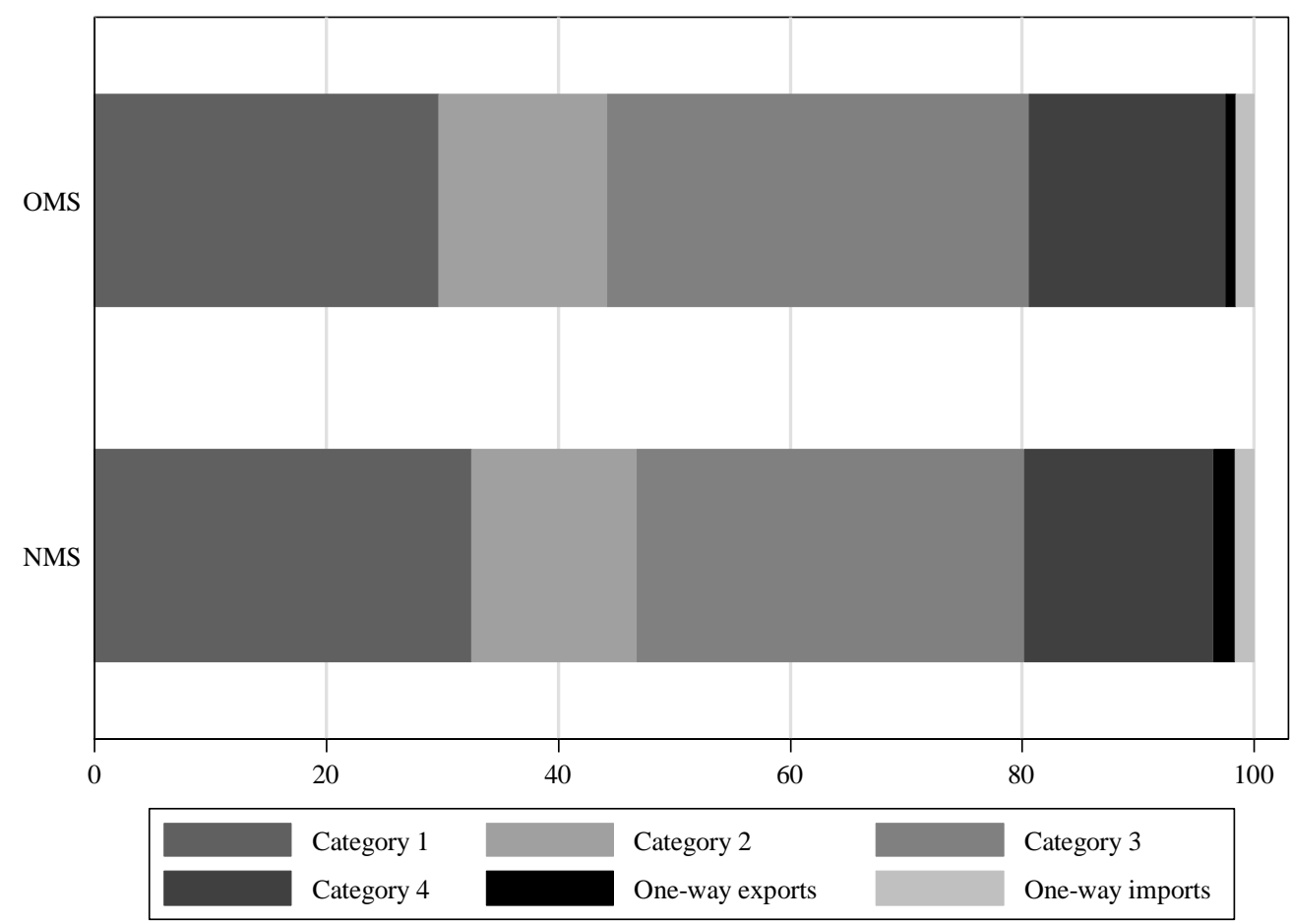

Figure 2. Price and quality competition categories and one-way agri-food trade for New (NMS) and Old Member States (OMS) (structures in \%, mean values, 2000-2011) Source: Own calculations based on UNSD (2013) Comtrade database with WITS (World Trade Integration Solution) software.

\section{RCA indices}

Figure 3 presents the calculated RCA indices for agri-food products with successful price competition (Category 1), successful quality competition (Category 3), and one-way exports. The RCA indices for Categories 1 and 3 are greater than one. These results indicate agri-food export competitiveness. The calculated RCA indices are mixed between greater and less than one for one-way exports. Except for Cyprus, Denmark, Lithuania, and Romania, the RCA indices for Category 3 are greater than for Category 1 . The empirical results confirmed strong revealed comparative advantages for products with successful quality competition and successful price competition. Except for Bulgaria, Cyprus, Denmark, Greece, Hungary, Ireland, Latvia, Lithuania, Malta, and Poland, this does not hold for one-way exports. 


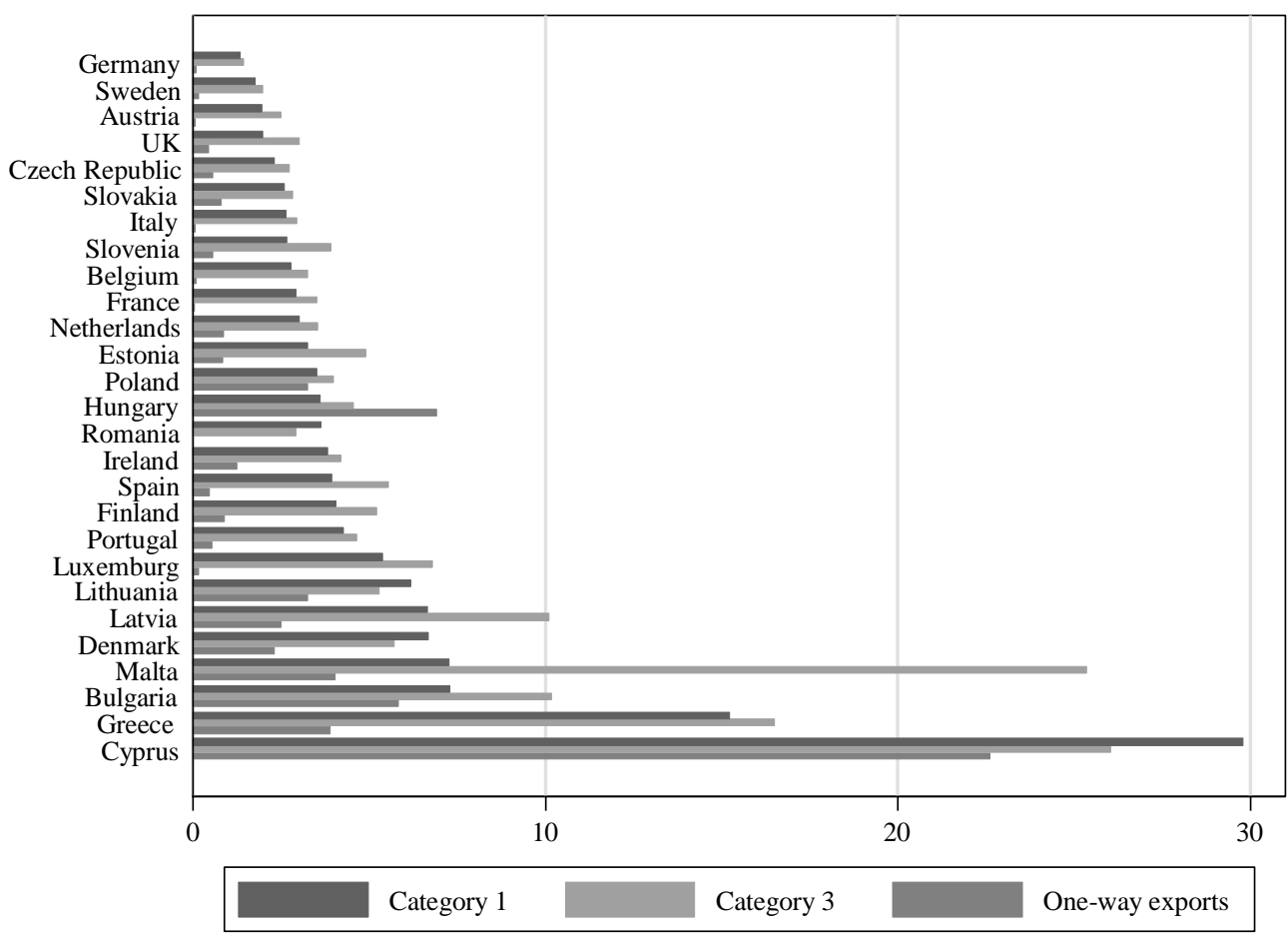

Figure 3. Mean of RCA indices for agri-food products with successful price competition, successful quality competition and one-way exports (mean values, 2000-2011) Source: Own calculations based on UNSD (2013) Comtrade database with WITS (World Trade Integration Solution) software.

Except for one-way agri-food exports in the OMS, both the NMS and OMS are competitive in agri-food exports in successful price and successful quality competition categories (Figure 4). This is also valid for one-way agri-food exports in the NMS. In general, the RCA indices are higher for the NMS than for the OMS. The Kruskal-Wallis tests show that there are not significant differences in mean RCA values of each category between the NMS and OMS, except for one-way agri-food exports. 


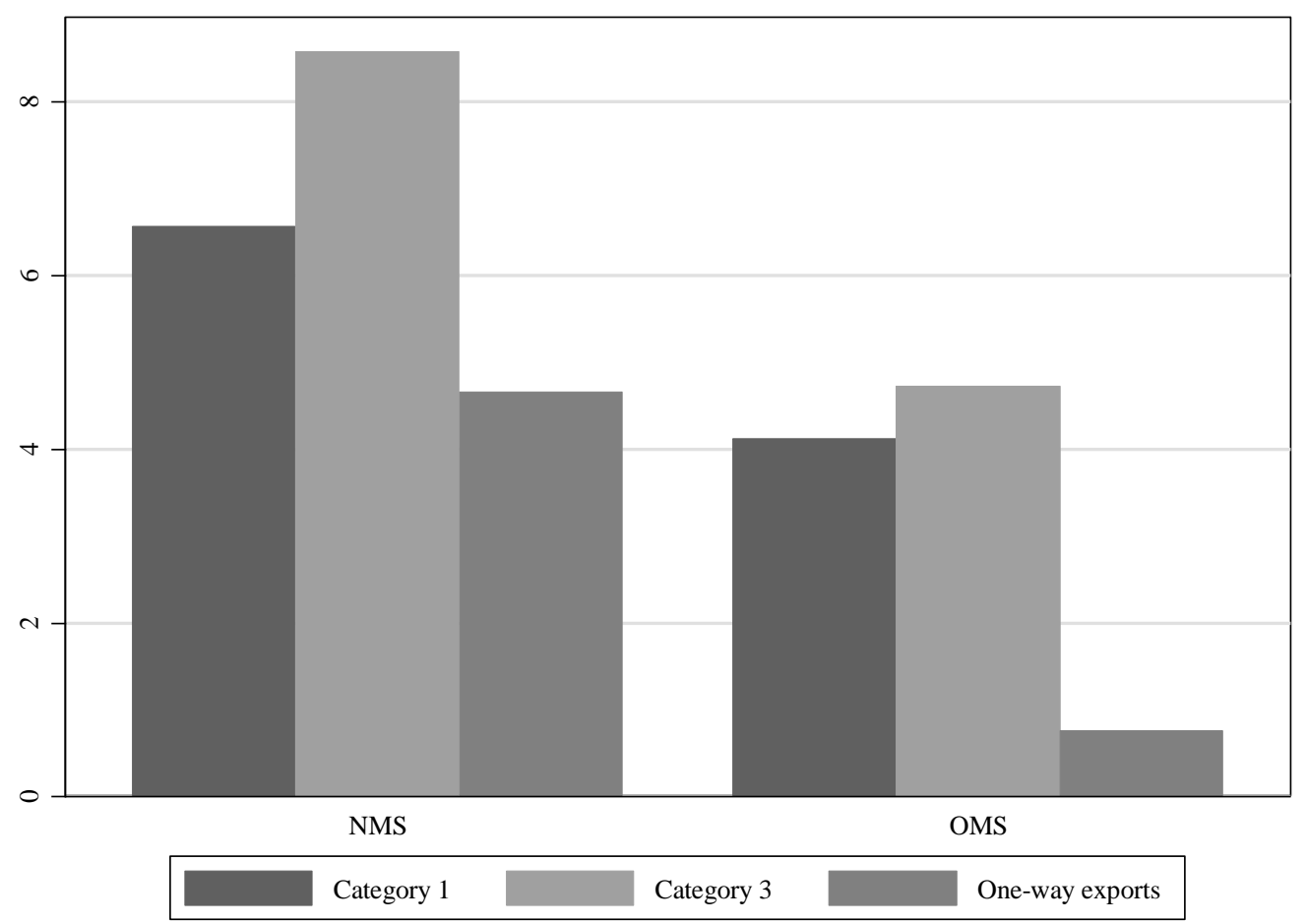

Figure 4. Mean of RCA indices for agri-food products with successful price competition, successful quality competition and one-way exports for the NMS and OMS (mean values, 2000-2011)

Source: Own calculations based on UNSD (2013) Comtrade database with WITS (World Trade Integration Solution) software.

\section{Kaplan-Meier survival rates for successful price and quality competition}

Because the share of one-way exports is negligible for each of the EU member states, thus we focus only on the Categories 1 and 3. Figure 5 presents the Kaplan-Meier survival rates for the Categories 1 and 3.

The duration of the Category 1 differs between the EU-27 member states. The KaplanMeier survival rates indicate a probability of continues survival of being with the successful price competition during the 12 year period. They are the highest (close to or more than $2 \%$ probability of the survival) for Spain, Poland, France, and Belgium. These countries have the longest duration of their successful price competition in agri-food trade. They were able to achieve agri-food trade surplus with lower export than import prices for continues longer period of time.

The duration of the Category 3 also differs between the EU-27 member states. The Kaplan-Meier survival rates in the year 12 for the successful quality competition are the highest (close to or more than $2 \%$ probability of the survival) for the following EU-27 
member states: the Netherlands, Spain, France, Italy, Belgium, Germany, and Hungary. These are the countries with the longest duration of the successful quality competition in agri-food trade. They were able to achieve agri-food trade surplus with higher export than import prices for continues longer period of time.

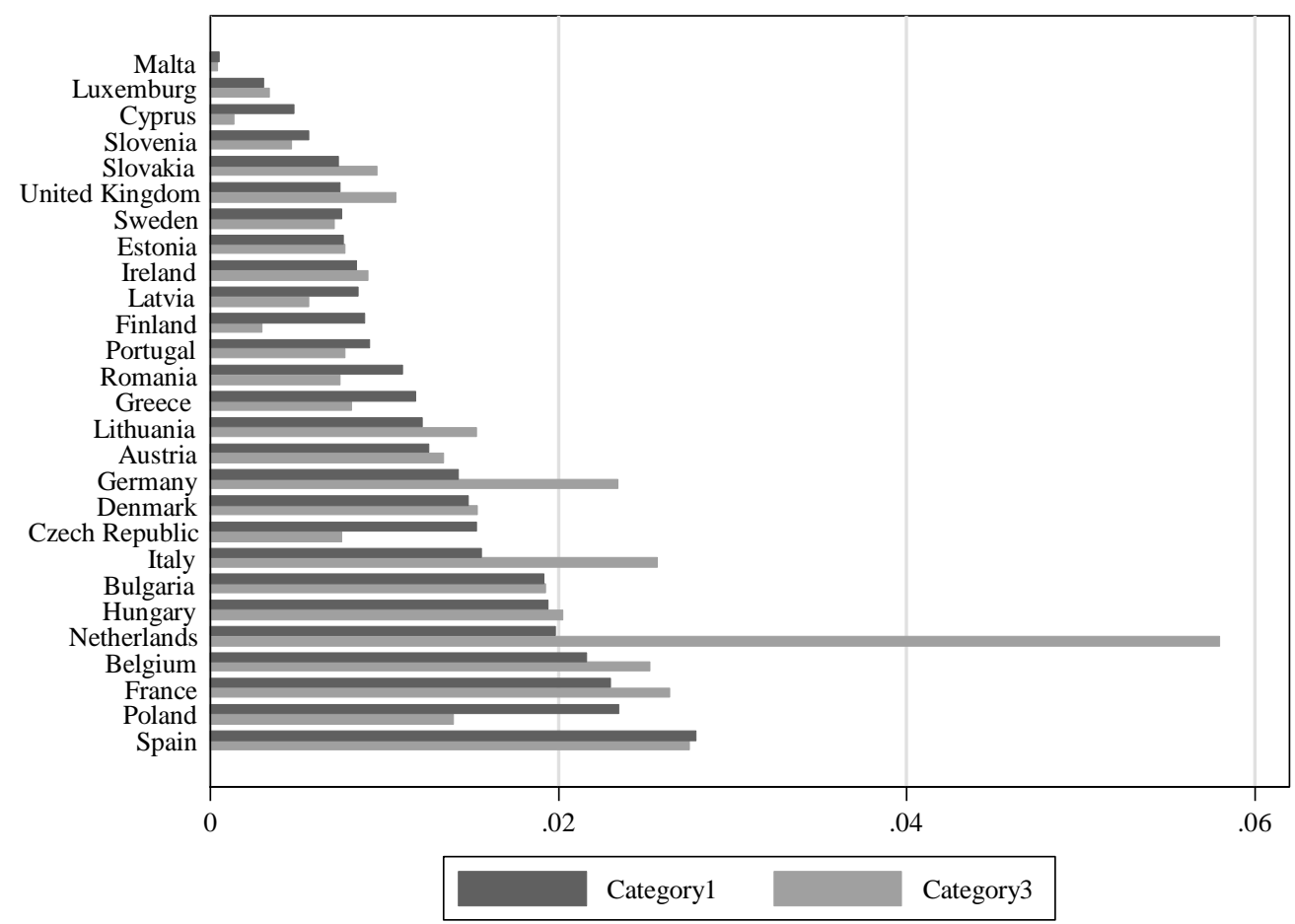

Figure 5. Kaplan-Meier survival rates for Categories 1 and 3 (year 12, 2011)

Source: Own calculations based on UNSD (2013) Comtrade database with WITS (World Trade Integration Solution) software.

\section{Kaplan-Meier survival rates for $R C A>$ indices}

Our focus is on the RCA>1 indices for agri-food products with the successful price competition (Category 1) and successful quality competition (Category 3 ). The results of the Kaplan-Meier survival rates for the RCA>1 indices confirmed that Categories 1 and 3 are consistent with revealed comparative advantages. As can be seen from Figure 6, the Kaplan-Meier survival rates for the RCA>1 indices for the Categories 1 and 3 agri-food products are relatively high. First, the Kaplan-Meier survival rates for the RCA $>1$ indices for agri-food products with the Category 1 are the highest for Finland, the Czech Republic, Romania, Hungary, and Poland. They experienced relatively longer duration of the export competitiveness for the Category 1 agri-food products with trade surplus which was achieved at lower export than import prices. Second, the Kaplan-Meier survival rates for the RCA>1 indices for the Category 3 agri-food products are the highest for the 
Netherlands, Italy, Hungary, Germany, Bulgaria, and Ireland. They experienced relatively longer duration of the export competitiveness for agri-food products with trade surplus which was achieved at higher export than import prices.

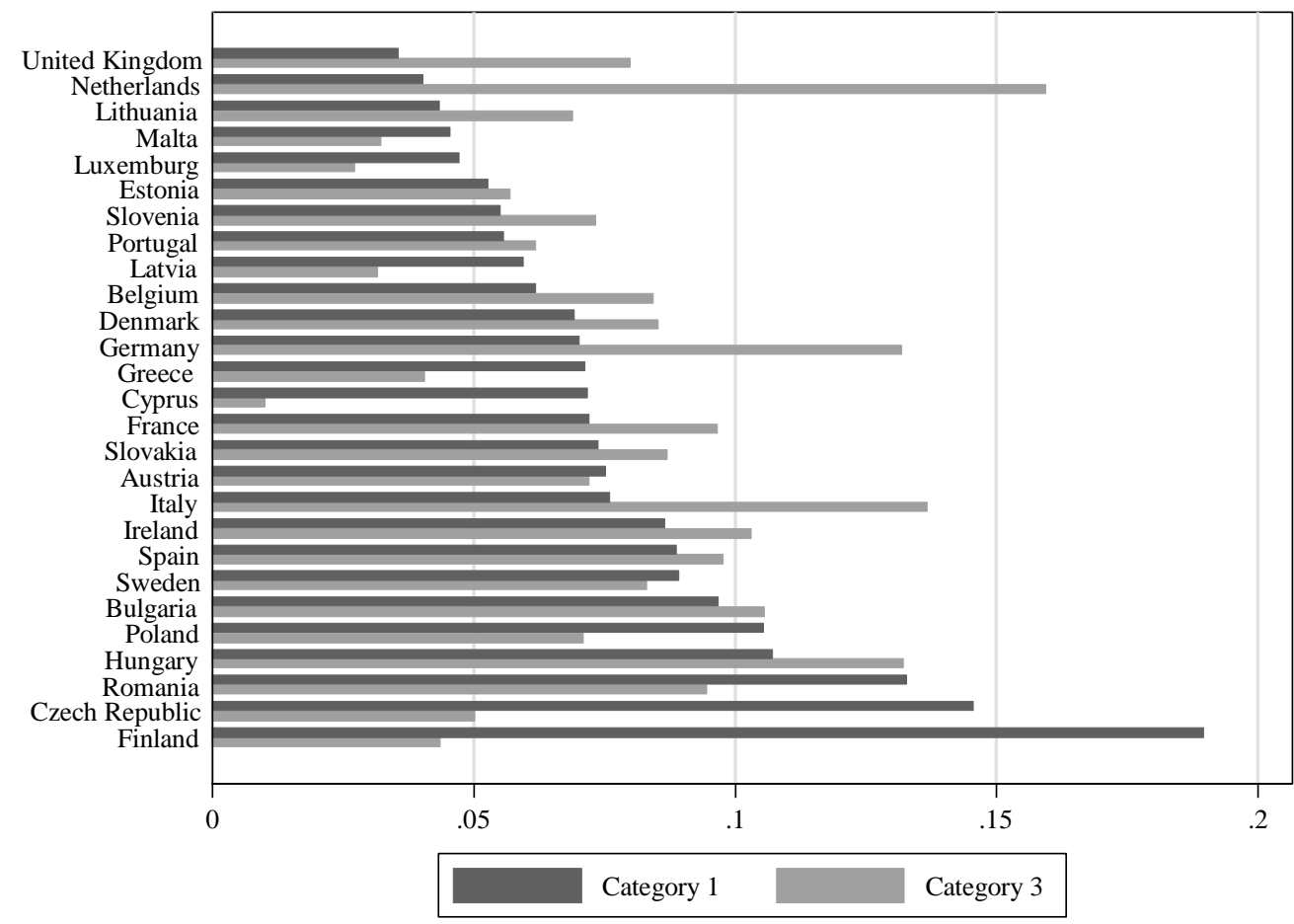

Figure 6. Kaplan-Meier survival rates for RCA>1 in Categories 1 and 3 (year 12, 2011) Source: Own calculations based on UNSD (2013) Comtrade database with WITS (World Trade Integration Solution) software.

As expected, the Kaplan-Meier survival rates are substantially higher for agri-food products in the Categories 1 and 3 with revealed comparative advantages (RCA>1) than those with revealed comparative disadvantages (RCA<1) (Figure 7). For the NMS the survival rates are the highest for Category 1 with RCA>1, while for the OMS the survival rates are the highest for Category 3 with RCA $>1$. The Kruskal-Wallis tests show that there are not significant differences at 5 per cent of significance level in mean values of each agri-food category between the NMS and OMS. 


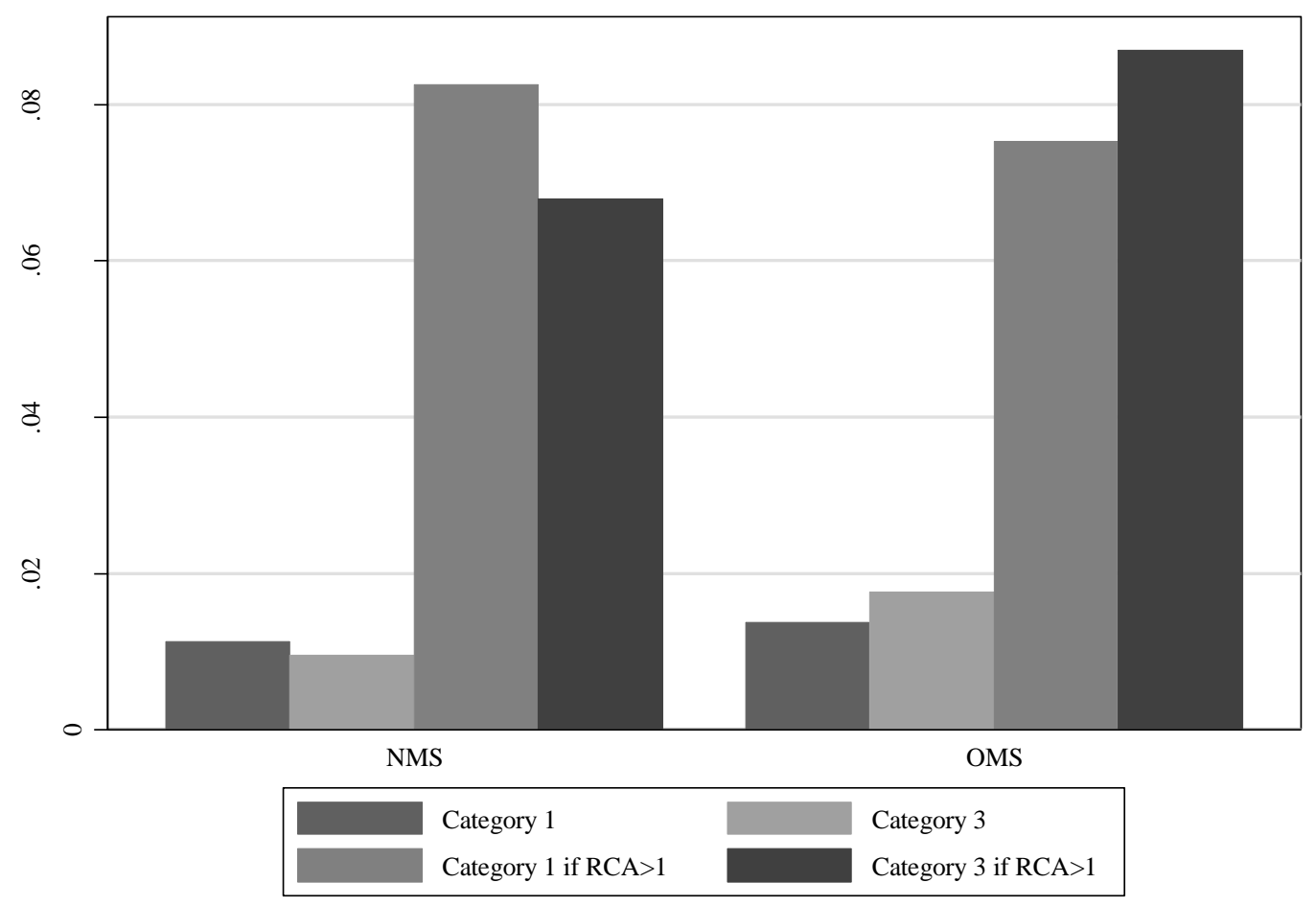

Figure 7. Kaplan-Meier survival rates for Categories 1 and 3 with and without RCA $>1$ for the NMS and OMS (year 12, 2011)

Source: Own calculations based on UNSD (2013) Comtrade database with WITS (World Trade Integration Solution) software.

\section{Conclusions}

This paper provides the empirical results on the importance of the NMS and OMS agrifood price competition and quality competition categories in the matched two-way trade, the one-way export/import shares, and revealed comparative advantage indices. According to these agri-food trade structures and comparative advantage analysis we can conclude that the NMS and OMS have become more similar.

A greater concentration in the NMS and OMS agri-food trade is on successful price competition and successful quality competition categories than on unsuccessful price competition and unsuccessful quality competition categories in the two-way matched trade. In spite of this, the EU has experienced declining share of EU agri-food exports in the global markets due to particularly rapid growth of agri-food exports in some emerging market economies (e.g. Bojnec et al. 2014). The proportion of agri-food trade pertains to the successful price competition is less important than the proportion of agri-food trade pertains to the successful quality competition. This implies that successful matched agrifood trade in similar products tends toward greater quality differentiation. This is consistent with the clear orientation of the EU Member States towards the exporting of 
higher value added, particularly agri-food products for final consumption. The results of successful quality competition are particularly robust for the Netherlands among the OMS and Poland among the NMS. The share of the one-way exports or imports in the EU-27 member states was of a relatively smaller size.

Successful price competition and successful quality competition are linked with revealed comparative advantage indices. Agri-food products with RCA $>1$ indices experienced relatively higher Kaplan-Meier survival rates in both Category 1 - successful price competition and Category 3 - successful quality competition.

Among issues for future research is to investigate and explore determinants of price and quality competition and factors of comparative advantages.

\section{References}

Aiginger, K., 1997. The use of unit values to discriminate between price and quality competition. Cambridge Journal of Economics, 21 (5), 571-592.

Aiginger, K., 1998. A framework for evaluating the dynamic competitiveness of countries. Structural Change and Economic Dynamics, 9 (2), 159-188.

Balassa, B., 1965. Trade liberalization and revealed comparative advantage. The Manchester School of Economic and Social Studies, 33 (2), 99-123.

Besedeš, T. and Prusa, T.J., 2006a. Ins, outs, and the duration of trade. Canadian Journal of Economics/Revue canadienne d'économique, 39 (1), 266-295.

Besedeš, T. and Prusa, T.J., 2006b. Product differentiation and duration of US import trade. Journal of International Economics, 70 (2), 339-358.

Bojnec, Š., 2001. Trade and revealed comparative advantage measures: regional and Central and East European agricultural trade. Eastern European Economics, 39 (2), 72-98.

Bojnec, Š . and Fertö, I., 2008a. European enlargement and agro-food trade. Canadian Journal of Agricultural Economics, 56 (4), 563-579.

Bojnec, $\breve{S}$. and Fertö, I., 2008b. Price competition vs. quality competition: the role of oneway trade. Acta Oeconomica, 58 (1), 61-89.

Bojnec, Š. and Fertő, I., 2009a. Agro-food trade competitiveness of Central European and Balkan countries. Food Policy, 34 (5), 417-425.

Bojnec, Š . and Fertö, I., 2009b. Determinants of agro-food trade competition of Central European countries with the European Union. China Economic Review, 20 (2), 327337.

Bojnec, Š. and Fertő, I., 2012a. Complementarities of trade advantage and trade competitiveness measures. Applied Economics, 44 (4), 399-408.

Bojnec, Š. and Fertő, I., 2012b. Does EU Enlargement Increase Agro-Food Export Duration? The World Economy, 35 (5), 609-631.

Bojnec, Š., Fertö, I. and Fogarasi, J., 2014. Quality of institutions and the BRIC countries' agro-food exports. China Agricultural Economics Review, forthcoming.

Carbone, A. and Henke, R., 2012. Sophistication and Performance of Italian Agri-food Exports. International Journal on Food System Dynamics, 3 (1), 22-34.

Cleves, M.A., Gould, W.W. and Gutierez, R.G., 2004. An Introduction to Survival Analysis Using STATA, Texas: Stata Press, College Station. 
Commission of the European Communities, 2011. Study on the Competitiveness of the European Meat Processing Industry. Brussels: Commission of the European Communities.

http://ec.europa.eu/enterprise/sectors/food/files/report_compmeat_en.pdf.

De Benedictis, L. and Tamberi, M., 2004. Overall specialization empirics: techniques and applications. Open Economies Review, 15 (4), 323-346.

Fertö, I., 2008. The evolution of agri-food trade patterns in Central European countries. Post-Communist Economies, 20 (1), 1-10.

Fertö, I. and Hubbard, L.J., 2003. Revealed comparative advantage and competitiveness in Hungarian agri-food sectors. The World Economy, 26 (2), 247-259.

Fertö, I. and Soós, K.A., 2009. Duration of trade of former communist countries in the EU market. Post-Communist Economies, 21 (1), 31-39.

Fisher, C., 2010. Food quality and product export performance: an empirical investigation of the EU situation. Journal of International Food and Agribusiness Marketing, 22 (3), 210-233.

FoodDrinkEurope, 2012. Priorities for the development of an EU industrial policy for food - Competitiveness Report 2012. Brussels: FoodDrinkEurope.

FoodDrinkEurope, 2014. Promoting an EU industrial policy for food and drink Competitiveness Report 2013-2014. Brussels: FoodDrinkEurope.

Gehlhar, M.J. and Pick, D.H., 2002. Food trade balances and unit values: what can they reveal about price competition? Agribusiness, 18 (1), 61-79.

Majkovič, D., Bojnec, Š. and Turk, J., 2007. Development of New Members' EU trade: evidence from the Slovenian agri-food sector. Post-Communist Economies, 19 (2), 209-223.

Stiglitz, J.E., 1987. The causes and consequences of the dependence of quality on prices. Journal of Economic Literature, 25 (1), 1-48.

Ulff, J. and Nielsen, M., 2000. Price-quality competition in the exports of the Central and Eastern European countries. Intereconomics, March/April, 94-101.

UNSD, 2013. Commodity Trade Database (COMTRADE), New York: United Nations Statistical Division, available through World Bank's World Integrated Trade Solution (WITS) software: www.wits.worldbank.org.

Vollrath, T.L., 1991. A theoretical evaluation of alternative trade intensity measures of revealed comparative advantage. Weltwirtschaftliches Archiv, 130 (2), 263-279.

Wijnands, J., Meulen, B. and Poppe, K., 2007. Competitiveness of the European food industry. An economic and legal assessment. Luxembourg: Office for Official Publications of the European Communities. 